\title{
Beden Çalışma Gücü Kaybı Değerlendirilen Olgularda Kurumlar Arası Karşılaştırma
}

\author{
Inter-Instutional Comparison on Working Power Loss Evaluated Cases \\ Volkan Ünal, Ferruh Baklacıoğlu, Esra Özgün Ünal, ZaferÇetinkaya, Muhammet Demir, Ahmet Sadi Çă̆dır
}

Adli Tıp Kurumu Başkanlı̆̆ $\imath$ İstanbul

${ }^{*}$ Bu çalışma 4-6 Haziran 2015 tarihleri arasında Isparta'da düzenlenen XII. Adli Bilimler Kongresi'nde poster bildiri olarak sunulmustur.

*Çalışma için Adli Tip Kurumu bilimsel kurulundan izin alınmıştır.

\section{Özet}

Amaç: Türkiye'de hastalıkları nedeniyle emekli olmak isteyen, ilgili tüzük ve yönetmelik hükümlerince bu kapsamda değerlendirilen kişiler 'malulen emekli' olarak tanımlanmaktadır. Sigortalı (çalışan) hastalığı veya hastalıkları nedeniyle hayatını çalışarak idame ettiremeyeceğini yazılı olarak bildirdiğinde, emekli olma isteğine ait hukuki süreç başlamaktadır. Öncelikle Sosyal Güvenlik Kurumu, itiraz halinde Sosyal Sigorta Yüksek Sağlık Kurulu kişiler hakkında rapor düzenlemektedir. Davacı veya davalının oluşan kararlara itirazı sonrasında ise Adli Tıp Kurumu 3. Adli Tıp İhtisas Kurulu kiși hakkında mütalaa düzenlemektedir.

$\mathrm{Bu}$ çalışma ile Adli Tıp Kurumu 3. Adli Tıp İhtisas Kurulu ve diğer kurumlar tarafından düzenlenen malulen emeklilik olgularındaki karar farklılıkların ortaya konulması ve tespit edilen bulgular eşliğinde uygulamada standardizasyon sağlanması amaçlanmaktadır.

Gereç ve Yöntem: Çalışmamızda 10 cak 2009-31 Aralık 2010 tarihleri arasında, Adli Tip Kurumu 3. Adli Tip İhtisas Kurulu tarafından düzenlenmiş kararlar geriye dönük olarak incelenerek, Sosyal Güvenlik Kurumu-Sosyal Sigorta Yüksek Sağlık Kurulu tarafından malulen emeklilik kapsamında olmadığ 1 bildirilen ancak kurul tarafından yapılan değerlendirmelerinde malulen emeklilik kapsamında olduğu tespit edilen olgular çalıșmaya dahil edilmiștir.

Bulgular: $\mathrm{Bu}$ vakaların yapılan ayrıntılı değerlendirmesinde; toplam 64 olgu tespit edilmiş, 57'sinin erkek, 7'sinin kadın olduğu tespit edilmiştir. Kadın olguların yaş ortalaması 50.71 olup erkek olguların yaş ortalaması 49.89 saptanmıştır. Tüm olguların yaş ortalamas 199.98 bulunmuştur.

Sonuç: Kullandıkları tüzük ve yönetmelik aynı olmakla birlikte aynı kişiler hakkında kurumlar arası karar farklılıkları oluşmaktadır. Tüzük ve yönetmelikler oluşturulurken uygulama prensipleri üzerinde tartıșılarak alınacak ortak kararlar, farklılıkların azalmasını ve emeklilik taleplerinin daha hızlı sonuçlanmasını sağlayacaktır. Kurumlar arası ortak toplantılar düzenlenerek vakalar tartış1labilmeli, karşılıklı değerlendirmeler sunulabilmelidir.

Anahtar Kelimeler: Beden Çalışma Gücü Kaybı, Kurumlar Arası Karşılaştırma, Adli Tıp.

\section{Giriş}

Türkiye'de hastalıkları nedeniyle emekli olmak isteyen, ilgili tüzük ve yönetmelik hükümlerince bu kapsamda değerlendirilen kişiler 'malulen emekli' olarak tanımlanmaktadır. Sigortalı (çalışan) hastalığı veya hastalıkları nedeniyle hayatını çalışarak idame ettiremeyeceğini yazılı olarak bildirdiğinde, emekli olma isteğine ait hukuki süreç başlamaktadır.

5510 sayılı kanuna göre malullük; kişinin ilk defa sigortalı

Sorumlu Yazar: Uzm.Dr. Volkan Ünal

Adli Tip Kurumu Başkanlı̆̆ı, İstanbul

E-mail: volkanunal75@yahoo.com

Geliş: 11.09.2015

Düzeltme: 02.12.2015

Kabul: 24.12 .2015

\section{Abstract}

Objective: In Turkey, individuals who want to retire due to illness and determined within the provisions of the relevant rules and regulations are defined as 'retirement due to disability'. When the insured apply with a petition, describing that $\mathrm{s} / \mathrm{he}$ cannot work because of the diseases, retirement process begins. First Social Security Institution in case of objection Social Security Supreme Council of Health prepares reports about individuals. Third Specialization Board of the Council of Forensic Medicine is the final expertise authority on these cases. With this study it is aimed to reveal the decision differences on 'retirement due to disability' cases between the Third Specialization Board of the Council of Forensic Medicine and the other institutions and, guided with the findings, to provide the standardization in practical implementation.

Materials and Methods: For this study; the reports of the 3rd Specialization Board of The Council of Forensic Medicine were retrospectively investigated and the cases who were reported as not suitable for the retirement due to diseases by Social Security Institution and Social Security Supreme Council of Health but reported as suitable for the retirement due to diseases by the $3^{\text {rd }}$ Specialization Board were included.

Results: Totally sixty four cases were determined. Fifty seven of the cases were male and seven of them were female. Average age of female cases was 50.71, male cases were 49.89 and average age of all cases was 49.98 .

Conclusion: Even the rules and regulations are same, there are differences between institutions. While rules and regulations are constituted, taking common decisions by negotiating on practice principles should reduce the differences between institutions and provide faster decision makings. Institutions should arrange routine meetings and discuss about the cases and present assessments interactively.

Keywords: Working Power Loss, Inter-Instutional Comparison, Forensic medicine.

olarak çalışmaya başladığı tarihten sonra meydana gelen veya önceden var olan ancak çalışmasına engel olmayan fiziksel ya da ruhsal hastalığının, engelinin; mevzuat hükümlerince belirlenen seviyede meslekte kazanma veya çalışma gücü kaybına yol açması halidir. Malulen emeklilik değerlendirmelerinde kişiler bağlı bulundukları sosyal güvenlik mevzuat hükümlerinden yararlanmaktadır $(1,2)$. Sosyal Sigortalar Sağlık İşlemleri Tüzüğü hükümlerince (85/9529 karar sayıl1) beden çalışma gücünün $2 / 3$ 'sini kaybeden kişiler malulen emekli olabilirken, 11.10.2008 tarihinde çıkarılan Çalışma Gücü ve Meslekte Kazanma Gücü Kaybı Oranı Tespit İşlemleri Yönetmeliği hükümlerince beden çalışma gücünün \%60'ını kaybeden kişiler malulen emekli 
olabilmektedir $(3,4)$.

3 Ağustos 2013 de Resmi Gazete'de yayımlanan yönetmeliğe göre ise; ilk defa çalışmaya başladığı tarihten sonra vücutlarında oluşan ve tedavi edilemeyen hastalıkları nedeniyle, çalışma gücünün en az \%60'ını kaybettiği veya vazifelerini yapamayacak şekilde meslekte kazanma gücünü kaybettiği kurum sağlık kurulunca tespit edilen sigortalı malul sayılmaktadır (5). Ülkemizde maluliyet, beden çalışma gücü kaybı (emeklilik) ve maluliyet oranlarının hesaplanması Çalışma ve Sosyal Güvenlik, Sağlık ve Adalet Bakanlıklarının sorumluluğundadır (6). Mahkemeler zaman zaman maluliyet oranlarını öğrenmek amacıyla tıbbi bilirkişilerden mütalaa almaktadır (7). Adli Tıp Kurumu kanununa göre malulen emeklilik, meslekte kazanma gücü kaybı olgularının değerlendirilmesine ait işlemler 3. Adli Tıp İhtisas Kurulu tarafından yürütülmektedir (8).

Dünya Sağlık Örgütü; psikolojik, fizyolojik veya anatomik bütünlüğün bozulması, fonksiyon kaybı veya azalmasını, vücutta eksilme olarak tanımlamış ve bu eksikliğinin uzaması sonucu kişinin kabul edilen normal sınırlar içindeki hareketleri yapamamasını maluliyet olarak nitelendirilmiştir (9). Ülkemizde maluliyet tespitinin yapılması için eski adı ile Sosyal Sigortalar Kurumu yeni adı ile Sosyal Güvenlik Kurumu tarafından düzenlenmiş tüzük ve yönetmelikler kullanılmaktadır (10). Maluliyet ile beden çalışma gücü kaybının farklı kavramlar olduğu ve farklı listelerden değerlendirme yapıldığ 1 bilinmektedir (11).

2006 yılı öncesinde malulen emeklilik değerlendirmeleri ilk olarak, çalışanların bağlı bulunduğu Emekli Sandığı, Bağ Kur, Sosyal Sigortalar Kurumu tarafindan yapilmakta iken, 2006 yılı sonrasında ise bu üç kurumun birleşmesi ile oluşturulan Sosyal Güvenlik Kurumu tarafından yapılmaktadır.

Bu çalışma ile Adli Tıp Kurumu 3. Adli Tıp İhtisas Kurulu ve diğer kurumlar tarafından düzenlenen malulen emeklilik olgularındaki karar farklılıkların ortaya konulması ve tespit edilen bulgular eşliğinde uygulamada standardizasyon sağlanması amaçlanmaktadır.

\section{Gereç ve Yöntem}

Çalışmamızda 1 0cak 2009-31 Aralık 2010 tarihleri arasındaki 2 yıllık süreçte Adli Tıp Kurumu 3. Adli Tıp İhtisas Kurulu tarafından düzenlenmiş kararlarda; Sosyal Güvenlik Kurumu-Sosyal Sigorta Yüksek Sağlık Kurulu tarafından malulen emeklilik talepleri reddedilmiş (beden çalışma gücünün 2/3’ünü kaybetmediği kararı verilen) ancak kurul tarafından yapılan değerlendirmelerinde malulen emeklilik kapsamında (beden çalışma gücünün 2/3’ünü kaybettiği) olduğu tespit edilen olgular retrospektif taranarak belirlenmiştir.
Olgular; yaş, cinsiyet, gönderildiği bölge, kurul rapor tarihi, hangi listeden malulen emeklilik kapsaminda değerlendirildikleri, başvuruların branşlara göre dağılımı, hangi kurum tarafından malulen emeklilik taleplerinin reddedildiği, malullük başlangıç tarihleri, kurul muayenesi yapılıp yapılmadığı, işe girdikten sonra hangi tarihte malul sayılmaları gerektiklerine dair düzenlenen kararlar, ayrıca maluliyet değerlendirmesi yapılıp yapılmadı̆̆ı, dekatlarına göre hastalık dağılımı ilişkisi yönünden değerlendirilmişlerdir.

\section{Bulgular}

Toplam 64 vaka tespit edilmiş olup; 57'si erkek, 7'sinin kadın cinsiyetinde olduğu saptanmıştır. Tüm olguların yaş ortalaması 49.98 olup, en küçük yaş 23 , en büyük yaş 78 bulunmuştur. Olguların yaşları dekatlara göre ayrıldığında en fazla olgunun 25 ile 5.dekatta olduğu görülmüş olup, diğer

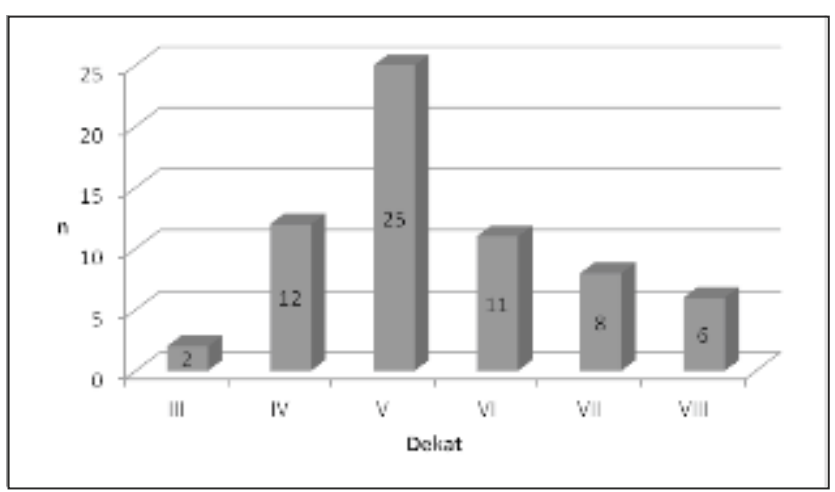

Şekil 1. Olguların dekatlarına göre dağılımı.

Olguların gönderildikleri bölgeler incelendiğinde; Güneydoğu Anadolu Bölgesinden 3, Akdeniz Bölgesinden 4, Doğu Anadolu Bölgesinden 6, Ege Bölgesinden 9, Karadeniz Bölgesinden 11, Marmara Bölgesinden 13, İç Anadolu Bölgesinden 18 olgu olduğu kayıtlıdır.

Beden çalışma gücünün 2/3'sini (üçteikisini) kaybeden olguların, verilen kurul kararlarının yapılan ayrıntılı değerlendirmesinde; 16 (\% 25) kardiyoloji, 14 (\% 21.87) nöroloji, 8 (\% 12.25) psikiyatri, 7 (\% 10.93) onkoloji, 7 (\%10,93) göz, 5 (\% 7.81) göğüs hastalıkları, 4 (\% 6.25) endokrinmetabolizma-iç hastalıkları, 3 (\% 4.68) ortopedi branşını ilgilendiren hastalık ve arızaları nedeniyle başvurularının olduğu tespit edilmiştir.

Üçüncü Kurul tarafından malulen emeklilik talepleri kabul edilen olguların Sosyal Sigortalar Sağlık İşlemleri Tüzüğü (SSSİT)'nde malulen emekli edilme sınıfları incelendiğinde; 17'sinin A (Baş Arızaları), 5’inin B (Göz Hastalıkları ve Görme Arızaları), 12'sinin D (Solunum, Dolaşım Sistemi Hastalıkları ve Sistemik Hipertansiyonlar), 3'ünün E (Karın Hastalık ve Arızaları), 4’ünün F (Hareket Sistemindeki Kemik, Kas, Eklem Hastalık ve Arızaları), 3’ünün G (İç Salgı Hastalıkları, 
Endokrin), 2'sinin K (Hematolojik Hastalık ve Arızalar), 1'inin L (Romatoloji), 1'inin O (Deri Hastalıkları ve Arızaları) listesinden verildiği kayıtlıdır. Onaltı olguda ise liste numarası belirtilmeden SSSİT hükümlerince malul sayılması gerektiğinin ilgili mahkemesine bildirildiği tespit edilmiştir. Kişilerin malulen emekli edildikleri listelere göre sayılar Şekil 2’de gösterilmiştirA listesinde değerlendirilen olgular

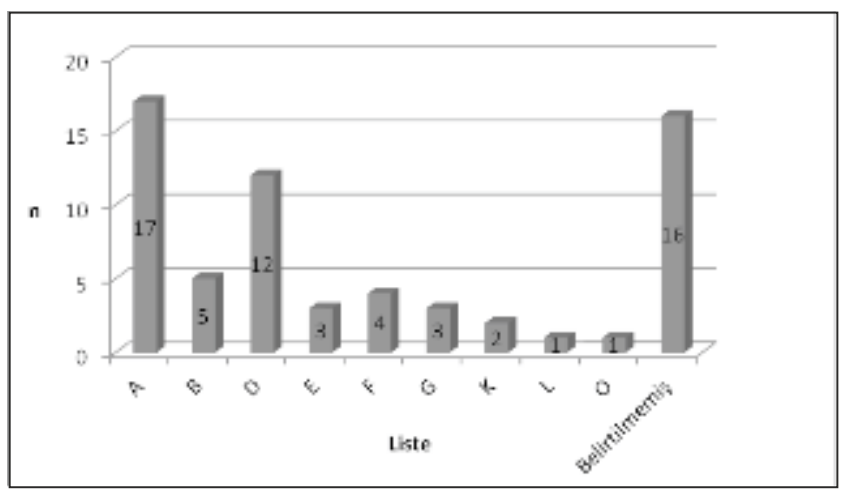

Şekil 2. Kişilerin malulen emekli edildikleri listeler.

incelendiğinde; 6’sının A2 (parezi, plejiler), 5’inin A14a (psikozlar), 1'inin A6 (serebroherediter, herododejeneratif hastalıklar), 1'inin A7 (serebellar hastalıklar), 3’ünün A11 (miyelin kılıfı hastalıkları), 1'inin A12 (epilepsi) maddeleri kapsamında oldukları tespit edilmiştir.

B listesinde değerlendirilen olgular incelendiğinde 5' inin de B17 (tashihle bilateral 0.2 ve altı düzeyinde görme) maddesi kapsamında olduğu tespit edilmiştir.

D listesinde değerlendirilen olgular incelendiğinde; 4'ünün D35 (solunum ve dolaşımın etkilendiği akciğer, kalp hastalıkları), 5’inin D36 (kalp hastalıkları), 3’ünün D37 (opere kalp hastalıkları) olduğu tespit edilmiştir.

E listesinde değerlendirilen olgular incelendiğinde; 2'sinin E41B (anal inkontinans), 1’inin E44 (karaciğer ve pankreas kanserleri) olduğu tespit edilmiştir.

F listesinde değerlendirilen olgular incelendiğinde; 1'inin F59 (omurga hareketlerini kısitlayıcı ankilozlar ve travma sekelleri), 1’inin F61 (kalça ekleminin iki taraflı tam ankilozu), 2'sinin F65 (yassı ve uzun kemiklerin ve omurganın her çeşit aktif, akıntılı osteidleri) olduğu tespit edilmiştir.

$\mathrm{G}$ listesinde değerlendirilen olgular incelendiğinde; 2'sinin 70a (tip II diabetes mellitus), 1’inin 70b (tip I diabetes mellitus) olduğu tespit edilmiştir.

$\mathrm{K}$ listesinde değerlendirilen olgular incelendiğinde; 1'inin K76 (lösemiler), diğerinin K83 (lenfoma, sarkomlar) olduğu tespit edilmiştir.

L listesinde değerlendirilen olgunun 85 alt sınıfından (ağır, ileri derecede ankiloz ve hareket kisitlanmasina neden olan romatizmal hastalıklar), 'O' listesinde değerlendirilen olgunun
97 alt sınıfından (tüm listelerde tespit edilen hastalık ve arızalar dışında kaldığı halde, tedavi edilemeyen ve çalışma imkânını ortadan kaldıran bir veya birkaç hastalık veya arıza) olduğu tespit edilmiştir.

Kadın olguların; 2' si A, 1'i B, 2'si G listesinden malulen emekli edildiği, 2' sinde ise liste numarası belirtilemeden malulen emeklilik kapsamında değerlendirildiği tespit edilmiştir.

Kişilerin malulen emeklilik taleplerinin reddedildiği kurumlar incelendiğinde (dosyada bulunan evrak kapsamında); toplam 48 olguda SSYSK kararının bulunduğu tespit edilmiştir. Tüm dağılım Şekil 3’te sunulmuştur..

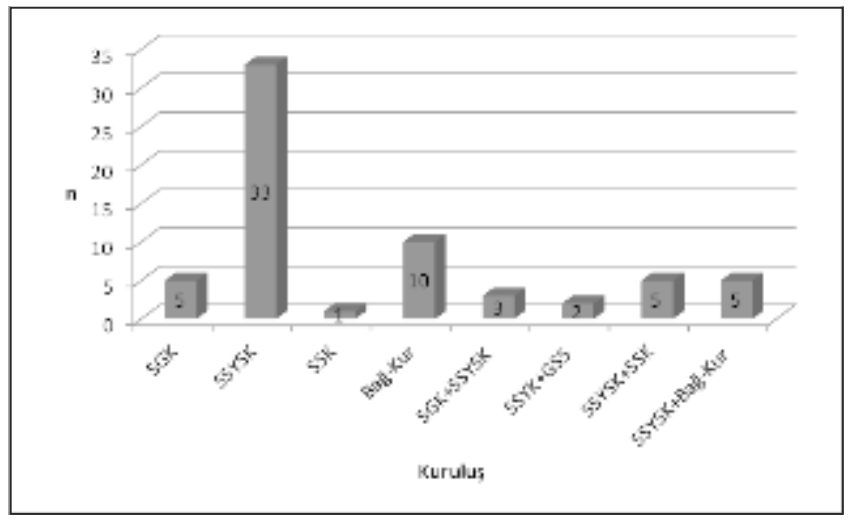

Şekil 3. Malulen emeklilik taleplerinin reddedildiği kuruluşlar.

Kişilerin SGK, SSYSK'dan malul olmadıklarına dair almış oldukları karar tarihi ile 3. İhtisas Kurulu'ndan verilmiş olan malul olduklarına dair kararlar arasında geçen süreler incelendiğinde; en kısa 9 ay, en uzun 90 ay olmak üzere; 0-12 ay olan $5,12-24$ ay olan $22,24-36$ ay olan $22,36-60$ ay olan 9,60 ay üstü olan dönemde 6 olgu olduğu tespit edilmiştir.

Kurul kararlarında malullük başlangıç tarihinin belirtildiği 26 olgu tespit edilmiştir. Kişilerin belirtilen (geri tarihe yönelik) malullük başlangıç tarihi ile 3 . Kurul kararı arasında kalan süreler incelendiğinde; 0-12 ay olan 6, 12-36 ay olan 6, 3660 ay olan $6,60-120$ ay olan 6,120 ay üzeri olan 2 olgu olduğu tespit edilmiştir.

Kişilere 3. Kurul tarafından malullük başlangıç tarihi belirtilen 26 olgunun ilgili tarihleri ile diğer kurumlar tarafından malulen emekliliğinin reddedildiği tarihleri karşılaştırıldığında; 14 olgunun malullük başlangıç tarihinin diğer kurumlar tarafından verilen karar tarihinin öncesinde olduğu, 12 olgunun malullük başlangıç tarihinin ise diğer kurumlar tarafından verilen karar tarihinden sonra olduğu tespit edilmiştir.

Malulen emeklilik başlangıç tarihi belirtilmiş olan 26 olgudan işe başlama tarihi belirtilen 12 olgu olduğu kayıtlıdır. $\mathrm{Bu} 12$ olgunun malullük başlangıç tarihlerinde kaç yıldır çalıştıkları incelendiğinde; 2 olgunun işe başlamadan 
öncesinde malul sayılması gerektiği, 1' inin ilk 5 yıl içinde, 4' ünün 5-10 yll içerisinde, 2 ' sinin 10-15 yıll içerisinde, 1' inin 1520 yıl içerisinde, 2 ' sinin 20 yıl üzerinde çalışıktan sonra malul olması gerektiği (malullük başlangıç tarihinin belirtildiği) tespit edilmiştir.

Tüm olguların 24'ünde malulen emeklilik değerlendirmesinin yanında maluliyet değerlendirmesi yapıldı $\breve{g}_{1}$ tespit edilmiştir. Maluliyeti değerlendirilen olgulardan meslekte kazanma gücünün \% 100’ünü kaybettiği tespit edilen 6 olgu bulunmaktadır. Bu olguların yapılan değerlendirmesinde; 2 A14A, 1 A2, 1 D37, 1 F65 maddesi kapsamından malulen emekli edildikleri, bir olguda ise madde numarası belirtilmeden malulen emekli olduğunun bildirildiği kayıtlıdır. Bu vakalarda Sosyal Güvenlik Kurumu tarafindan verilen red tarihi ile kurul karar tarihi arası 0-12 ay arası olan 1 olgu, 24-36 ay arası olan 3 olgu, 36-60 ay arası olan 2 olgu bulunmaktadır. Bu olguların dördünde diğer kurumlar tarafından yüzdelik oranlarla; $80,80,76,70$ maluliyet oranı verildiği tespit edilmiştir.

Olguların işe giriş tarihleri açısından yapılan değerlendirmesinde 48 olguda işe giriş tarihinin bildirilmediği (dosyada bulunamadığı) tespit edilmiştir.

Kurul tarafından düzenlenen kararlarında malulen emekliliği hangi maddeden olduğu belirtilmeyen 16 olgu bulunduğu, bu olguların 7'sinde ayrıca maluliyet değerlendirmesinin yapılarak, hem maluliyet hem de malulen emeklilik açısından değerlendirme yapıldığı tespit edilmiştir.

Altmış dört olgudan 62' sinin 3. İhtisas Kurulu tarafından muayene edildiği, 2 olgunun ise muayene edilmeden dosya kapsamı üzerinden ihtisas kurulu kararının düzenlendiği kayıtlıdır. Birisinin whipple ameliyatlısı, diğerinin tedaviye rağmen tam iyileşme sağlanamayan myelodisplastik sendrom olduğu tespit edilmiştir.

Altmış dört olgunun hastalık etiyolojisi incelendiğinde; 1 kişinin trafik kazası, 1 kişinin iş yerinde duvar yıkılması, 2 kişinin travma, 1 kişinin ateşli silah yaralanması, 1 kişinin operasyon sırasında yanlış kan transfüzyonu sonucu, 1' inin doğuştan gelen hastalı̆̆ sonucu talebinin olduğu, 57 kişinin kendinde mevcut hastalıklar ve arızalar sonucu başvurduğu, 4 olgunun iş kazası niteliğinde olduğu tespit edilmiştir.

Kurulda muayene edilen kişilerin mevcut muayenelerinde; 8 kişinin göz muayenesinde görme düzeyinin en fazla $2 / 10$ seviyesinde olduğu, 11 kişinin nöroloji muayenesinde hemipleji, parapleji ve/veya inkontinans olduğu, 4 kişinin psikiyatri muayenesinde şizofreni, 1 kişinin psikiyatri muayenesinde orta düzey mental retardasyon, 5 kişinin ortopedi muayenesinde iskelet sisteminde ankiloz tespit edildiği kayıtlıdır. Yirmidokuz olgunun direkt muayene sonucunda tespit edilen bulgularına göre ilgili tüzük kapsamında malulen emekli edilebilecekleri major muayene bulguları olduğu tespit edilmiştir.

Kişilerin belirtilen kurumlar tarafından emeklilik taleplerinin reddinden sonra sağlık durumunda değişiklik olup olmadığg (belirtilen tarihlerdeki tıbbi evrak üzerinden) incelendiğinde; 5 olguda görme düzeyinde azalma, 1 olguda böbrek yetmezliğinde ilerleme, 5 olguda kalp yetmezliği rahatsızlığında ilerleme, 1 olguda epileptik atakların sıklığında artma, 3 olguda solunum yetmezliğinde ilerleme, 2 olguda mevcut nörolojik sekel düzeyinde ilerleme, 1 olguda meme kanseri gelişimi, 1 olguda yürüme kısıtllı̆ı̆ında artma, 1 olguda yara yeri enfeksiyonu gelişimine bağlı kısıtlılık artışı olduğu tespit edilmiş olup, 44 olguda ise tıbbi durumda değişiklik olup olmadığı yönünde tespit yapılamamıştır.

Dekatlarına göre hastalıkların dağılımına bakıldığında;

Üçüncü dekattaki kişilerin hastalıkları; 1'inin hipertrofik kardiyomyopati, diğerinin orta mental retarde olduğu, dördüncü dekatta; 2'sinin multipl skleroz, 4 şizofreni, 1 retinitis pigmentoza, $1 \mathrm{FMF}+\mathrm{KBY}, 1$ guillenbare, $1 \mathrm{KOAH}, 1$ görme azlığı, 1 hemipleji olduğu, beşinci dekatta; 3 'ünün kalp yetmezliği, 2'sinin by pass, 2 SVO, 1 multipl skleroz, 2'sinin ependimom, 1 menengiom, 1 meme kanseri, 1 rektum kanseri, 1 parapleji, 1 epilepsi, 4 görme kusuru, 2 şizofreni, 1 kronik osteomyelit, $2 \mathrm{KOAH}, 1$ olivopontoserebral atrofi olduğu, altıncı dekatta; 1'inin kalp yetmezliği, 2'sinin kapak replasmanı, 1'inin kalp pili, 2 sinin hemipleji, 2 sinin DM, 1 inin pankreas kanseri, 1' inin myelodisplastik sendrom, 1 ' inin organik psikoz olduğu, yedinci dekatta; 2'sinin hemiparezi, 1'inin epidural kitle-tümör, 1 kalp yetmezliği, 1 DM, 1 Romatoit artrit, 1 kifoskolyoz, 1 her iki kalça ankilozu olduğu, sekizinci dekatta; 2'sinin kalp yetmezliği, 2'sinin kardiyomyopati, 1 aort diseksiyonu, 1’inin görme azlığı olduğu tespit edilmiştir.

\section{Tartışma}

5510 sayılı kanuna göre malullük aylığına hak kazanma koşulları; kişinin yazılı talebinin olması, 1800 gün uzun vadeli sigorta kolları primi bildirilmiş olması, en az 10 yıldan beri sigortalı bulunması, malul sayılmış olması şeklinde bildirilmektedir (2). Hastalık ve arızaları nedeniyle çalışamayacak durumda olan, ancak belirtilen sigorta prim günü ve sigortalı olma şartlarını yerine getiremeyen kişiler, usul yönünden malulen emeklilik kapsamı dışında kalacaklardır.

Öncelikle yazilı olarak sevk talebinde bulunan sigortalının sevk işleminin yapılacağ sağlanmakta, sonrasında Sosyal Güvenlik Kurumu (Bölge) Sağlık Kurulları tarafından malul olup olmadığ verilmekte, itiraz halinde ise Sosyal Sigorta Yüksek Sağlık Kurulu tarafından dosyalar karara bağlanmaktadır (2). 
Davacının oluşan kararlara itirazı sonrasında ise Adli Tıp Kurumu 3. Adli Tıp İhtisas Kurulu kişi hakkında mütalaa düzenlemektedir. Kişi hakkında kurul tarafından da malulen emeklilik talebinin reddedildiği tespit edilirse bu vakalar son olarak Adli Tip Kurumu Genel Kuruluna başvurabilmektedir (8). İşleyiş sırası kapsamında tüm olguların öncelikle Sosyal Güvenlik Kurumu, sonrasında ise Sosyal Sigorta Yüksek Sağlık Kurulundan karar alması beklenmekle birlikte, çalışmamızda 48 olguda Sosyal Sigorta Yüksek Sağlık Kurulu kararı olduğu tespit edilmiştir. Bazı mahkemelerin özellikle iş kazası olgularında, işleyiş sırasına uymadan Adli Tıp Kurumuna dosyayı gönderebildiği bilinmekle birlikte, dosyalarında Yükssek Sağlık Kurulu kararı bulunmayan 16 olgu hakkında bir karar düzenlenmiş olabileceği ancak dosya kapsamına dâhil edilmemiş olabileceği düşünülmektedir.

Kurula malulen emeklilik değerlendirmesi talebiyle gönderilen dosyalarda yapılan inceleme sonucunda kişiler hakkında malulen emekli olacaklarına dair kurul kararı oluştuğunda, resmi son bilirkişi merci Adli Tıp Kurumu olduğundan mahkeme, Kurumun kararını onaylamakta ve kişiler Yargıtay içtihatları doğrultusunda malulen emeklilik maaşı almaya hak kazanmaktadır.

Malulen emeklilik değerlendirmelerinin yapıldığ 1 Ek-1 listelerinde kişinin hastalık ve arızaları değerlendirilirken, hangi mesleği icra ettiğinin herhangi bir önemi bulunmamaktadır. Kişilerin mesleğine göre yapılan değerlendirme, meslek grup numaraları üzerinden maluliyet tayininde kullanılmaktadır. Beden çalışma gücü kaybı (2/3 ve \% 60/malulen emeklilik) değerlendirmeleri ile maluliyet oranları değerlendirmelerinin farklı kavramlar olduğu ve farklı listelerden değerlendirme yapıldığı bilinmekle birlikte, ilgili tüzük ve yönetmelikler değerlendirildiğinde (mutlak olmamakla birlikte çoğunda), maluliyet Ek-3 listesinde arıza ağırlık ölçüsü 57 ve üzeri olan hastalık ve arızaların, beden çalışma gücü kaybının değerlendirildiği (Ek-1) listelerinde (2/3 ve \% 60) bulundukları görülmektedir. Sosyal Sigortalar Sağlık İşlemleri Tüzüğü hükümlerinde bu durum şu şekilde açıklanmaktadır: 'Ek -3 listesinde (Yukarıda sayılmadığı halde Tüzüğe ekli A cetvelinin listelerinde yer alan ve arıza ağırlık ölçüsü 57 olan hastalık ve arızaların meydana geldiği, meslek grup numarası 1 olan sigortalılar, $\mathrm{C}$ cetvelindeki sürekli iş göremezlik simgesinin A olması şartıyla çalışma gücünün $2 / 3$ ünü yitirmiş sayılırlar'). Ancak 11.10.2008 tarihli yönetmelikte (\% 60 değerlendirmelerinde) bu ibare kaldırılmış ve tam olarak malulen emeklilik değerlendirmesi ile maluliyet kavramının farklı kavramlar olduğu sunulmuştur. Bu duruma göre kişinin \% 65 maluliyet oranının olması, onun malulen emeklilik kapsamında değerlendirileceğini ifade etmemektedir. Yalnızca meslek hastalığı veya iş kazası olgularında meslekte kazanma gücünün \% 60'ını kaybeden kişinin talebi olması halinde malulen emeklilik kapsamında değerlendirilebileceği 11.10.2008 tarihli yönetmelikte belirtilmektedir $(3,4)$. Çalışmamızda 6 olgu hakkında 3. İhtisas Kurulu tarafından $\% 100$ oranında maluliyet verildiğinin tespit edildiği, bu kişilerin malulen emeklilik taleplerinin diğer kurumlar tarafından reddedildiği de göz önüne alındı̆̆ında, maluliyet değerlendirmesinin malulen emeklilik değerlendirmesine karıştırılmaması gerektiği ortaya çıkmaktadır. Bu 6 olgunun dördünde diğer kurumlarca \% 66.6’nın üzerinde maluliyet oranı verilmesine karşın malulen emeklilik taleplerinin aynı kurumlar tarafından reddedilmiş olması, beden çalışma gücü kaybı ile meslekte kazanma gücü kaybının değerlendirme farklılıklarını ortaya koymaktadır.

Ertürk ve arkadaşlarının yaptığı çalışmada 278 olgunun, 115’inin (\% 41.36) çalışma gücünün en az 2/3’ünü kaybettiği, malulen emeklilik için gelen olguların \% 25.4'ünün onkolojik hastalıklar, 2. sirada ise \% 14.9'unun diabet nedeniyle başvuruda bulunduğu belirtilmiştir (12). Çalışmamızdaki başvurular branş dağılımlarına göre değerlendirildiğinde, ilk sırada kardiyoloji, 2.sırada nörolojik hastalık ve arızaların bulunduğu görülmektedir. Onkolojik hastalıklar ise göz hastalıkları ile birlikte 4.sırada yer almaktadır.

İçmeli ve arkadaşlarının yaptığı çalışmada Adli Tıp Kurumuna Ocak 2003-Eylül 2006 arasında kardiyolojik hastalıklar sebebiyle çalışma gücü kaybı tespiti açısından başvuran 36 olgunun retrospektif olarak incelemesinde 15 (\% 41.66) kişinin çalışma gücünün en az 2/3’ünü kaybettiği belirtilmiştir (13). Çalışmamızda malulen emeklilik talepleri kabul edilen 64 olgunun 16'sının (\% 25) kardiyolojik hastalıkları nedeniyle başvurusunun olduğu tespit edilmiştir.

İçmeli ve arkadaşlarının yaptığı diğer bir çalışmada Sosyal Sigorta Sağlık İşlemleri Tüzüğüne göre değerlendirilen 111 kişiden 59'unun (\% 53.15) SSSİT hükümleri kapsamında çalışma gücünün en az 2/3’ünü kaybettiği belirtilmiştir (14). Özbay'ın uzmanlık tezinde 2000-2002 yılları arasında değerlendirilen 243 iş kazası olgusunun 35’inin (\% 14.4) tam malul (meslekte kazanma gücü kaybı oranı \% 60-100 arasında) olduğu belirtilmiştir (15). Çalışmamızda beden çalışma gücünün 2/3'sini kaybettiği tespit edilen 64 olgu saptanmış olup, iş kazasına bağl1 4 olgu bulunduğu tespit edilmiştir.

Sosyal Güvenlik Kurumunun hastalıkları nedeniyle malulen emeklilik kapsamında değerlendirdiği, ancak yapılan ihbar sonrası malulen emekliliklerini kaldırdığ 2 olgunun Adli Tip Kurumu 3. Adli Tip İhtisas Kurulunca yapılan incelemesinde; epilepsi tanısı olan kişinin malulen emeklilik kapsamında değerlendirildiği, lomber disk herni operasyonu sonrası nörolojik defisit kalmayan olgunun ise beden çalışma gücünün 2/3'sini kaybetmediği, malulen emekli 
olamayacağının mahkemesine bildirildiği kayıtlıdır (11). Aynı vakaların benzer süreçler içerisinde malulen emeklilik açısından değerlendirilmesinde, kurumlar arası karar farklılıklarının oluştuğu bildirilen çalışmada olduğu gibi, çalıșmamızda da 2 yıllık süreç içerisinde 64 olgu hakkında kurumlar arası malulen emeklilik karar farklarının oluştuğu tespit edilmiştir. Ancak çalışmamızda tespit edilen olgulara ait kayıtlarda ihbar mektubu bulunmayıp, doğal işleyişe uygun olarak Sosyal Güvenlik Kurumu kararı sonrası kişilerin Adli Tip Kurumu'na başvurduğu tespit edilmiştir.

Beden çalışma gücünün 2/3'sinin değerlendirildiği Ek-1 listesinde 'myokard enfarktüsünün tanı olarak tespit edilmesi halinde' malulen emeklilik kapsamında değerlendirilmesi, çıkarılan tüzüğün o günün şartları ve tıp biliminin durumu ile doğru orantılı olduğunu göstermektedir. Mevcut \% 60 listelerinde ise kişinin myokard enfarktüsü geçirmesi malulen emeklilik kapsamında değerlendirilmesi için yeterli olmayıp, uygulanan tedavi sonrası halen devam eden fiziksel zorlanma hali, patolojik muayene bulgusu, NYHA 3-4 sinıfinda olması durumlarında, kısaca özetlenecek olursa uygulanan tedaviye rağmen hastalığının tam olarak iyileşmediğini gösteren tıbbi tablonun tespiti halinde malulen emeklilik kapsamında değerlendirilebileceği bildirilmektedir. Yine $2 / 3$ listesine göre bilateral 0.2 ve altı görme düzeyi bulunan kişiler malulen emekli olabilirken, \% 60 listesinde bu düzeyin bilateral 0.1 ve altı seviyesine çekildiği görülmektedir $(3,4)$. Yüzdesel oranlamaya bakıldığında beden çalışma gücünün $2 / 3$ ' sini (\% 66.6) kaybetmek daha zor gibi görünse de, 11.10.2008 tarihli Ek-1 listesinde tanımlı \% 60 listelerinde malulen emekliliğ e hak kazanmak yukarıdaki örneklerde olduğu gibi daha zor görünmektedir. Ancak bu durumu, gelişen tıp ilmi, hastalıkların eskiye oranla daha yüksek oranlarda tedavi edilebilirliği, sağlanan rehabilitasyon programları ile kalan sekel bulguların en aza indirilmesi ile açıklayabiliriz.

Tipta geçerli olan 'hastalık yoktur hasta vardır' prensibi burada geçerlilik kazanmakta ve tanısı aynı olan, ancak bulguları birbirinden farklılık arz eden çok sayıda vaka tespit edilmektedir. Örneğin serebrovasküler hastalık geçirmiş iki farklı kișide kalan sekel sağ hemiparezi değerlendirilecek olunursa, birinde üst ve alt ekstremite sağ taraf kas gücü $2 / 5$, diğerinde 4/5 düzeyinde olabilmektedir. Tespit edilen başka patolojik muayene bulgusu olmaması durumunda kas gücü $2 / 5$ düzeyinde olan kişi malulen emekli kabul edilecekken, kas gücü 4/5 düzeyinde olan kişinin hâlihazırda ilgili tüzük ve yönetmelik hükümlerince malulen emekli olamayacağ 1 bilinmektedir. Bu durum, SSSIT 2/3 Ek-1 listesinde 'yürüme güçlügüu yaratan hemiparezi’ şeklinde tanımlanmış olmakla birlikte, \% 60 listesinde 'ağır hemiparezi' șeklinde tanımlanmıștır $(3,4)$. Her iki vakada da tanı aynı olmakla birlikte, bulgu farklılığından dolayı oluşan karar içerikleri de değişiklik gösterebilmektedir. Bu tür vakalar değerlendirilirken Ek-1 listelerinde sadece tanının yer alması, malulen emeklilik değerlendirmelerinde standart sağlamayı zorlaştırmakta ve kişi hakkında verilecek kararı, kurumların uygulama prensiplerine bırakmaktadır.

Beden çalışma gücü kaybı değerlendirmesinde hâlihazırda (01 Eylül 2013 sonrasindaki davalarda) 03.08.2013 tarih 28727 sayılı Maluliyet Tespiti İșlemleri Yönetmeliği Ek-1 listesi kullanılmaktadır. İlgili yönetmelikte hastalık ve arızalar, çalışmamızda değerlendirilen $2 / 3$ listesine göre daha sistematik ve ayrıntılı şekilde belirtilmiştir. Süreç olarak ilerleyen Ek-1 (1985, 2008, 2013) listelerinde sinfflandırmalar da ilerlemiş ve tanılara yönelik yapılacak değerlendirmeler ayrıntılı olarak irdelenmiştir. Kardiyak değerlendirmelerde NYHA sınıflaması, nörolojik ve ortopedik sekellerde efektif ambulasyon tanımlaması, tüm transplantasyonların malulen emeklilik kapsamına alınması, onkolojik değerlendirmelerde (örneğin lösemi) kişilerin tanı konulduğu anda malulen emekli edilmesi ve sonrasında yanıt değerlendirmesine göre yeniden değerlendirileceğinin belirtilmiş olması, eski tanımlamalara göre daha net sınıflandırmalar yapıldığını göstermektedir. Burada önemli olan dava tarihinde (veya herhangi bir iş kazası veya meslek hastalığı mevcutsa olay tarihinde) hangi tüzük ya da yönetmeliğin geçerli olduğunu tespit ederek kararı o hükümlere göre vermektir (5). Ancak yine de tüm hastalık ve arızalar için oluşturulacak ayrıntılı değerlendirme parametrelerine ihtiyaç olduğu açıktır.

11.10.2008 tarihli yönetmelik hükümlerince; 'eski ve çalışmaya engel olmayan bir arızanın, arıza hastalık listesinde (Ek-1) belirtilen seviyelere yükseldiği’ kurum sağlık kurulunca tespit edilen sigortalılar malul sayılmaktadır (4). Burada belirtilmek istenen; kișinin ișe giriș öncesi var olan hastalık ve arızalarına bağlı olarak beden çalışma gücünün \%60'ını kaybetmediği durumlarda mevcut tanısı/bulguları ile işe girebileceği ancak sonrasında hastalık bulguları ilerlerse malulen emeklilik kapsamında değerlendirilebileceğidir. Sosyal Güvenlik Kurumunun düzenlediği bazı kararlarda; 'kişinin mevcut hali ile beden çalışma gücünün $2 / 3$ sini veya $\%$ 60'ını kaybettiği (malulen emeklilik kapsamında değerlendirildiği) ancak mevcut tanısı ile işe girdiğinden malulen emekli sayılamayacağının' bildirildiği bilinmektedir. $\mathrm{Bu}$ kişilerin Sosyal Güvenlik Kurumu kanununa göre işe girerken muayenelerinin yapıldığı, alınan sağlık kurulu raporları ile işe girdikleri bilinmektedir. Mevcut tanıları ile çalışmaya başladıktan belli süre sonra hastalık talebiyle çalışamayacaklarını beyan ettiklerinde, olay dava haline dönüşerek hukuki süreç başlamaktadır. Alınan sağlık kurulu raporları esas alınarak bu kișilerin belirlenen iş kollarında 
bazen yıllarca çalıştığ 1 ancak SGK kararında mevcut tanısı ile işe girmesi nedeniyle malulen emeklilik taleplerinin reddedildiği görüilmektedir. Sağlık kurulu raporlarındaki karar kısmında 'kişilerin çalışabilir' olması ve bunun üzerine kişinin SGK hükümlerince işe alınıp, sigortalı olarak belirli süre çalışması ve sonrasında mevcut bulgularının ilerlemesi, değerlendirilmesi gereken bir kriter olarak karşımıza çıkmaktadır. Bu tür hastalığı olan vakalarda işe giriş sırasında daha ayrıntılı muayene ve tetkikler yapılarak kişinin belirlenen iş kolunda çalışıp çalışamayacağının belirlenmesi, periyodik kontrollerinin sağlanmasının uygun olacağını düşünmekteyiz. İşe girişleri sırasında çalışabilir raporu alan kişilerin 'mevcut tanısı ile işe girmesi nedeniyle' malulen emeklilik talebinin reddedilmesinin, yönetmelikte tanımlı madde ile çeliştiğini ve yeniden değerlendirilmesi gereken konular arasında olduğunu düşünmekteyiz.

Kişinin tanısı konulduğu andan itibaren öncelikle tedavisinin uygulanması gerektiği ve kalan sekel üzerinden malulen emeklilik kapsamında değerlendirileceği yönünde ilgili tüzük ve yönetmeliklerde vurgu mevcuttur $(3,4)$. Beden çalışma gücünün 2/3' sini veya \% 60'ını kaybettiği bildirilen sigortalı artık malulen emekli olmaya hak kazandığından, ikinci değerlendirilecek husus kişinin hangi tarihten itibaren malulen emekliliğinin başladı̆̆ıdır. Burada yapılan değerlendirme genel olarak kişinin mevcut tanısına yönelik tespit edilen bulgularının hangi tarihten itibaren sekel olarak yorumlandığ 1 ve çalışamaz hale geldiğinin tespiti ile ilgilidir. Belirtilen tarihten itibaren kişi malulen emekli maaşı almaya hak kazanacaktır. Çalışmamızda SGK, SSYSK tarafından yapılan değerlendirmelerinde talepleri reddedilen 5 olgunun, kurul tarafından yapılan değerlendirmesinde; 0-12 ay içerisinde malulen emeklilik kapsamında değerlendirilmesi, aynı listelerde yazılı metinlerin kurumlar arasında farklı yorumlanabildiğini göstermektedir. Oniki olguda ise kurul tarafından verilen malullük başlama tarihinin SGK, SSYSK karar tarihlerinden sonra olması, bu kişilerin hastalık ve tanılarına yönelik bulgularında zaman içerisinde ilerleme gözlendiğini ve bu nedenle kurumlar arası karar değişikliğine sebebiyet verdiğini göstermektedir.

Kurul tarafından yapılan değerlendirmelerinde, malullük başlangıç tarihleri son 1 yıl içerisinde olan 6 olgunun bulunması, bu kişilerin hastalık ve arızalarının son 1 yıl içerisinde ilerlediğini göstermektedir. Ondört olgunun malullük başlangıç tarihinin diğer kurumlar tarafından düzenlenen ve malullük taleplerinin reddedildiği karar tarihinden önce olması, kurumların benzer süreçlerde yaptığ 1 değerlendirmelerde farklı kararlar alabildiğini ortaya koymaktadır.

Sosyal Güvenlik Kurumu malulen emeklilik talebiyle başvuran kişilere ait dosyaları değerlendirirken gerektiğinde kontrol muayenesi isteyip hastanın verilen kontrol süresi sonrasında yeniden kontrollerinin yaptırılmasını talep ederek, kişi hakkında mevcut durumuna göre karar düzenleyebilmektedir. Üçüncü İhtisas Kurulunun tüm kararlarında ise Sosyal Güvenlik Kurumu tarafından düzenlenen kararlarda olduğu gibi, kontrol muayenesi veya belli bir süre sonra kontrole çağrılması gerektiği ibaresi yer almamaktadır. Çalışmamızda 2 olgunun işe başlamadan önce malulen emekli kabul edilmesi gerektiği tespit edilmiştir. $\mathrm{Bu}$ tür olgularda işe giriş muayenesi, kişinin mevcut iş kolunda çalışıp çalışamayacağının başlangıçta değerlendirilmesi önem arz etmektedir.

Kurulda tüm olguların 62'sinde muayene yapıldığg ve bu vakaların 29'unda direkt muayene bulgusuna göre malulen emeklilik kapsamında değerlendirilebilecek düzeyde bulgu tespit edilmiş olması, muayenenin bu tür olgularda karar oluşturulurken çok önemli bir değeri olduğunu göstermektedir. Yönetmelikte belirtilen hali ile Sosyal Güvenlik Kurumunun bu tür hastalar hakkında karar verirken, belirlediği sağlık kuruluşlarından alınan raporlar üzerinden değerlendirme yaptığ 1 bilinmektedir. Üçüncü İhtisas Kurulunda yapılan değerlendirmelerde ise muayeneye katılan hekimlerin, oluşan kurul kararına imza attığı bilinmektedir. Adli tıp alanının simülasyona açık olduğu da göz önüne alındığında birebir muayene daha da önemli hale gelmektedir.

Aynı hastalık, tanıya sahip olmasına rağmen tüzük veya yönetmelik hükümlerince farklı kişiler arasında; tetkik sonuçlarına, muayene bulgularına, hastalığının sekel niteliğine göre farklı kurum ve kurul kararları oluşabildiği görülmektedir. Hastalığ 1 nedeniyle malulen emeklilik kapsamında değerlendirilen kişilerin sekel bulguları net değilse, sık periyotlarla kontrol muayenelerinin yapılması gerektiği bildirilmektedir (11). İki kurum açısından karar farklılıkları irdelendiğinde; SGK/SSYSK kararlarını oluştururken dosyada olmayan tıbbi evrakın kurul değerlendirmesinde dosyada olabildiği, 3. İhtisas Kurulu'na başvurulduğunda sürecin biraz daha ilerlemiş olduğu, kurul muayenesi ve tetkik sonuçlarında kişilerin tanısına yönelik tespit edilen sekel bulguların, laboratuar bulgularının ilerlemiş olabildiği tespit edilmiştir.

\section{Sonuç}

Kullandıkları tüzük ve yönetmelik aynı olmakla birlikte, aynı kişiler hakkında kurumlar arası karar farklılıkları oluşabilmektedir.

$\mathrm{Bu}$ tür vakalar değerlendirilirken kurum kararlarını oluşturacak hekimlerin, hastanın yapılacak muayenesine katılması önem arz etmektedir. İşe giriş sağlık kurul 
raporlarında, tanısı bulunan hasta çalışanlar için ayrıntılı muayene kayıtları, tetkik sonuçları oluşturularak belirlenen iş kollarında çalışıp çalışamayacakları değerlendirilmeli ve diğer vakalara göre periyodik muayenelerinin (çalışılan iş koluna da bağlı olarak) daha sık tekrarlanması sağlanmalıdır.

Tüzük ve yönetmelikler oluşturulurken alınacak ortak karar ve uygulama prensipleri ile aynı nitelikte veya benzer kararların oluşumu artırılarak, davaların daha kısa sürede sonuçlanması ve çelişkilerin azaltılması sağlanmalıdır. Kurumlar arası ortak toplantılar düzenlenerek vakalar tartışılabilmeli, karşılıklı değerlendirmeler sunulabilmelidir.

Tüm tanılar, hastalık ve sekel arızalar için oluşturulacak ayrıntılı tıbbi değerlendirme bulguları standardizasyon sağlanmasına katkıda bulunacak, bu da oluşacak kararlarda benzer yaklaşımları meydana getirecektir. Oluşturulacak olan malulen emeklilik değerlendirme listelerinde, tanısal ibarelerin yanında muayene bulgularının, tetkik sonuçlarının, hastalık tablolarının da tanımlanarak, tüm parametreler eşliğinde, oluşacak kararlar açısından standardizasyon sağlanması kolaylaştırılmalıdır. Yapılacak olan düzenlemelerle, malulen emeklilik taleplerinin dava haline dönüşmesinin önüne geçilerek sürecin hızlandırılması sağlanmalıdır.

\section{Kaynaklar}

1. Birgen N, Okudan M, Okyay M, İnanıcı MA. A Calculation of Percent Disability in Occupational Injury Cases: a Forensic Assessment. The Bulletin of Legal Medicine. 1999;4(3):101-8.

2. Law on the Social Security and General Health Insurance. Law No:5510 Turkish Official Journal 16.06.2006;26200.

3. Rules on the Changes of Social Security Health Procedure Rules. Turkish Official Journal 03.07.1985; 18800.
4. Working Power and Vocational Incapacity Ratio Determination Process Regulation. Turkish Official Journal 11.10.2008; 27021.

5. Regulation on the disability determination process. Turkish Official Journal 03.08.2013;28727.

6. Sözen Ş, İnce H, Dikici F, Diraçoğlu D, İnce N. Maluliyet (Meslekte Çalışma Gücü Kayıplarının) Hesaplanması. Klinik Gelişim. 2009;22(1):122-5.

7. Acar K, Ardıç F, Toraman F. Forensic Medicine Investigation of 21 Bone Fracture Cases who had been Treated by Physical Therapy. The Bulletin of Legal Medicine. 1996;1(2):64-7.

8. The Law on The Council of Forensic Medicine. Law No: 2659. Turkish Official Journal 20.04.1982;17670.

9. International classification of functioning, disability and health: ICF. Geneva: World Health Organization; 2001.

10. Social Security Health Procedure Rules. Turkish Official Journal 22.06.1972; 14223

11. Ünal V, Özgün Ünal E, Çetinkaya Z, Yener Z, Koral F, Dilim $\mathrm{H}$, et al. Evaluation of Retirement Upon a Notice: Two Case Reports Turkish Journal of Forensic Sciences. 2015;14(1):20-4.

12. Ertürk S, Ege B, Yemişçigil A, Aktaş EÖ. Maluliyet Oranı Saptanan Olguların Özellikleri, 1. Ulusal Adli Tıp Kongresi, İstanbul: Adli Tıp Kurumu Başkanlığı Yayınları; 1998. S. 139-42.

13. İçmeli ÖS, Şahin E, Şen H, Tavşanoğlu S, Birgen N. Kardiyolojik Hastalıklarda Beden Çalışma Gücü Kaybının Değerlendirilmesi, 13. Ulusal Adli Tıp Günleri, Antalya: Adalet Bakanlığ 1 Adli Tıp Kurumu Yayınları; 2006. s.242-3.

14. İçmeli ÖS, Baklacıŏ̆lu F, Anolay N, Ömeroğlu E, Özata AB, Birgen N. Beden Çalışma Gücü Kaybının Değerlendirilmesinde, Özürlülere Verilecek Sağlık Kurulu Raporları Hakkında Yönetmelik ile Sosyal Sigortalar Sağlık İşlemleri Tüzüğü’nün Farklılıklarının Araştırılması 12. Ulusal Adli Tıp Günleri, Antalya: Adalet Bakanlığ 1 Adli Tıp Kurumu Yayınlar1; 2005. s.294-7.

15. Özbay M. İş Kazalarında Meslekte Kazanma Gücü Kaybı Oranı Tespitinde Ülkemiz İle Diğer Ülkelerde Kullanılan Baremlerin Karşılaştırılması. İstanbul: Uzmanlık Tezi. T.C.Adalet Bakanlığı Adli Tıp Kurumu Başkanlığı, 2004. 